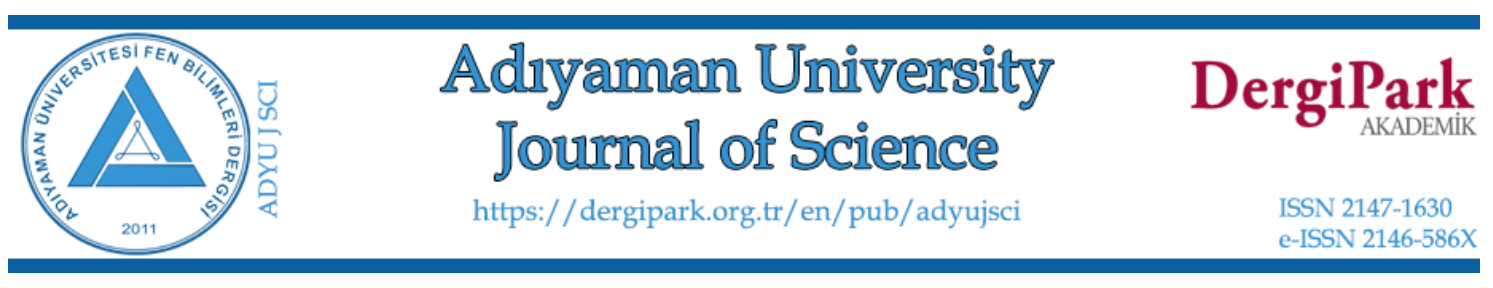

\title{
Cloning of ADAMTS2 Gene and Colony Formation Effect of ADAMTS2 in Saos-2 \\ Cell Line Under Normal and Hypoxic Conditions
}

\author{
Sümeyye AYDOGAN TÜRKOĞLU1,*, Sinem GÜLTEKİN TOSUN ${ }^{2}$ \\ ${ }^{1}$ Ballkesir University, Faculty of Science and Literature, Department of Molecular Biology and Genetics, \\ Balıkesir, Turkey \\ saydogan@balikesir.edu.tr,ORCID: 0000-0003-1754-0700 \\ ${ }^{2}$ Erciyes University, Institute of Health Sciences, Faculty of Veterinary Medicine, Department of \\ Genetics, Kayseri, Turkey \\ sinemgultekin@outlook.com, ORCID: 0000-0002-3927-0089
}

\begin{tabular}{lll}
\hline Received: 03.05.2020 & Accepted: 25.09.2020 & Published: 30.12.2020
\end{tabular}

\begin{abstract}
ADAMTS2 (a disintegrin and metalloproteinase with thrombospondin motifs 2), an Npropeptidase isoenzyme, is an enzyme involved in collagen biosynthesis by providing the amino ends of procollagen to be cut away. ADAMTS2 has anti-angiogenic activity as well as provides the processing of collagen. With this activity, it has become a target in cancer studies. Hypoxic regulation is a process that affects the expression of a large number of genes at the cellular level. Within the scope of our study, the cloning of the ADAMTS2 gene and its expression in Saos-2 (human bone carcinoma) cell line were performed ectopically. For this purpose, the transient transfection of the expression vector containing ADAMTS2 coding sequence was transfected by the calcium-phosphate precipitation method. Recombinant ADAMTS2 mRNA expression was checked by Real-Time PCR in Saos-2 cells. It was observed that there was a 50 -fold increase in ADAMTS2 mRNA expression in the transfected Saos-2 cells compared to the control group. Then, the effect of recombinant ADAMTS2 on the colony-forming potential of Saos-2 cells was investigated in both normal and chemically induced hypoxic conditions. Colony formation was reduced in Saos-2 cells, in which ADAMTS2 was expressed ectopically under normal conditions
\end{abstract}


compared to control group cells. Also, a stronger reducing effect on the colony-formation potential of ectopic expression in hypoxic conditions in Saos-2 cells was determined. In this study, the strong inhibitory effect of ADAMTS2 in hypoxic conditions was determined in Saos-2 cells for the first time.

Keywords: Cloning; ADAMTS2; Saos-2; Hypoxia; Ectopic expression; Colony formation.

\section{ADAMTS2 Geninin Klonlanması ve ADAMTS2'nin Saos-2 Hücre Hattında Normal ve Hipoksik Koşullarda Koloni Oluşumuna Etkisi}

\section{$\ddot{O} \mathbf{z}$}

$\mathrm{N}$-propeptidaz izoenzimlerinden ADAMTS2 (a disintegrin and metalloproteinase with thrombospondin motifs 2), prokollajenlerin amino uçlarının kesilip uzaklaştırılmasını sağlayarak kollejen biyosentezinde görev alan bir enzimdir. ADAMTS2, prokollajenlerin işlenmesinin yanı sıra anti-anjiyojenik aktiviteye de sahiptir. Bu aktivitesi ile kanser çalışmalarında bir hedef haline gelmiştir. Hipoksik regülasyon hücresel düzeyde çok sayıda genin ifadesini etkileyen bir süreçtir. Çalışmamız kapsamında ADAMTS2 geninin klonlanması ve ektopik olarak Saos-2 (insan kemik karsinomu) hücre hattında ifadesi gerçekleştirilmiştir. Bu amaçla ADAMTS2 kodlayıcı sekans içeren ekspresyon vektörünün, Saos-2 hücrelerine kalsiyum-fosfat presipitasyonu ile geçici transfeksiyonu gerçekleştirilmiştir. Rekombinant ADAMTS2'nin Saos-2 hücrelerinde ektopik olarak üretilip üretilmediği vektör transfekte edilmeyen hücrelerdeki ADAMTS2 mRNA ifadesi ile kontrol edilmiştir. Transfekte edilen Saos-2 hücrelerinde ADAMTS2 mRNA ifadesi kontrol grubuna kıyasla 50 kat artış olduğu gözlenmiştir. Daha sonra rekombinant ADAMTS2'nin Saos2 hücrelerinin koloni oluşturma potansiyeli üzerindeki etkisi hem normal hem de kimyasal olarak indüklenmiş hipoksik koşullarda incelenmiştir. Kontrol grubu hücrelerine kıyasla normal koşullarda ektopik ifadenin sağlandığı Saos-2 hücrelerinde koloni oluşumu azalmıştır. Ayrıca Saos-2 hücrelerinde hipoksik koşullarda yapılan ektopik ifadenin hücrelerin koloni oluşturma potansiyellerini üzerinde daha güçlü yönde azaltıcı etkisi tespit edilmiştir. Çalışmamızda, ilk kez ADAMTS2'nin hipoksik koşullarda güçlü inhibe edici etkisi Saos-2 hücrelerinde belirlenmiştir.

Anahtar Kelimeler: Klonlama; ADAMTS2; Saos-2; Hipoksi; Ektopik ifade; Koloni formasyon.

\section{Introduction}

Carcinogenesis occurs with abnormalities in many cellular processes such as cell cycle control, apoptosis, extracellular matrix remodeling (ECM), and metastasis. It is well known that carcinogenesis is associated with ECM remodeling. ECM has a structural and regulatory function 
in cells and tissues. Collagen, fibronectin, laminin, elastin, and proteoglycans are important ECM proteins. Collagen, which is one of the main components of ECM, gains structure by forming a helical structure of three collagen polypeptide subunits [1-4].

During collagen biosynthesis, collagen is synthesized as the precursor molecule and then processed into its mature. First, collagen is synthesized as an intracellular precursor molecule in connective tissue fibroblasts. The first synthesized collagen precursor is pre-procollagen. Then mature collagen fibers are formed undergoing various modifications [5, 6]. Molecules having many protease activities play a role in the proteolytic processing of the extracellular matrix. These molecules are grouped as a large number of protein families according to their domain structure. The first group is serine proteases; tissue plasminogen activator contains thrombin, plasmin, and urokinase. The second group is matrix metalloproteases (MMP); they are highly conserved $\mathrm{Zn}^{+2}$ dependent endopeptidases consisting of 23 members. These two groups play a role in ECM destruction and cancer metastasis. The third group is bone differentiation protein 1/tolloid family metalloproteases. The fourth group is transmembrane glycoproteins called ADAM (A Disintegrin and Metalloprotease; Disintegrin Metalloproteases) involved in cell-cell adhesion and proteolysis $[7,8]$.

Classified as procollagen N-propeptidases, ADAMTS2 (a disintegrin and metalloproteinase with thrombospondin motifs 2), ADAMTS3, and ADAMTS1 are known as procollagen cutting isoenzymes and play an important role in collagen biosynthesis. The ADAMTS2 gene is localized on the long arm (5q35.3) of the 5th chromosome and has 22 exons. It weighs $134 \mathrm{kDa}$ and consists of 1211 amino acids [9]. ADAMTS2, one of the $\mathrm{N}$-propeptidase isoenzymes, has also anti-angiogenic activity as well as the processing of procollagen. The antiangiogenic activity of ADAMTS2 has been demonstrated by a study in nude mice. Recombinant ADAMTS2 was transfected into cells after tumor formation in mice by HEK cellsand it was observed that tumor formation decreased rapidly when ADAMTS2 was overexpressed. For this reason, tumor vascularization has been decreased and ADAMTS2 has been proven to be directly anti-tumor related. Besides, in vitro studies performed as a different step of the study showed that recombinant ADAMTS2 rapidly induced apoptosis of endothelial cells [10].

Hypoxic regulation is a process that affects the expression of a large number of genes at the cellular level. With hypoxia occurring in cells, many genes, especially HIF-1 (Hypoxiainducible factor-1), are activated. HIF-1 is responsible for detecting changes in cellular oxygen concentration and creating responses. In hypoxic conditions, two main signaling systems are activated in the body: the AMPK pathway (AMP-activated protein kinase; adenosine monophosphate-activating protein kinase) and the HIF pathway (hypoxia-inducible factor; 
hypoxia-inducible factor) [11]. When the intracellular ATP level decreases, the AMPK pathway activates and accelerates catabolic processes, and inhibits anabolic processes. HIF creates a cellular response in mammalian cells as a result of oxygen deficiency (hypoxia) [12].

pVHL (von Hippel-Lindau protein) also takes part in the oxygen detection mechanism. HIF-1, which plays a key role in hypoxia, has important functions. HIF-1 consists of the oxygensensitive subunit $\alpha$ and the structural subunit $\beta$. In hypoxic conditions, HIF-1 $\alpha$ escapes proteasomal destruction, accumulates in the cytosol, becomes stable, phosphorylated, and passes to the nucleus, forming a heterodimeric complex. This complex binds to the enhancer region of the hypoxia-inducible genes or binds to the HRE (hypoxia response element), a 50-base pair DNA binding motif, and initiates transcription of target genes [13].

Studies in the literature on ADAMTS2 show that ADAMTS2 protein is important for the cell in the process of cancer as well as in collagen biosynthesis. We investigated the colony formation effect of ADAMTS2 in Saos-2 cells. The colony formation effect of ADAMTS2 was investigated in normal and chemically mimicked hypoxic conditions. The chemical hypoxia model is used to mimic low oxygen conditions in mammalian cells, as it generates a biochemical and molecular response at low oxygen conditions. Cobalt chloride $\left(\mathrm{CoCl}_{2}\right)$ solution was used while creating the chemical hypoxia model. $\mathrm{CoCl}_{2}$ added to the cell growth medium binds to proline hydroxylases, which inhibits HIF-1 under normal oxygen conditions, and stops their activity. Thus, HIF-1 cannot be hydroxylated and cannot be degraded. It becomes stable like the situation in oxygen deficiency. Thus, HIF-1 increases expression levels by stimulating other genes regulated by hypoxia.

In our study, ADAMTS2, which shows activity in both physiological and pathophysiological processes, has been cloned into the expression vector and transfected into Saos-2 (Osteosarcoma Cell Line). The colony formation effect of ADAMTS2 was investigated in Saos-2 cells in normoxic and hypoxic conditions.

\section{Materials and Methods}

\subsection{Materials}

Human sarcoma cell line (Saos-2) was obtained from Dr. Kennent Brown, University of Cardiff, UK. All tissue culture reagents were purchased from Invitrogen and the chemicals were purchased from Sigma-Aldrich. Cloning and expression primers were acquired from Macrogen. Primers were designed and analyzed using the OligoAnalyzer tool from IDT (Integrated DNA Technologies). 


\subsection{Strategies for the cloning of human ADAMTS2}

For primer design, the possible gene region of the human ADAMTS2 gene was first determined using the records in the NCBI. The PCR enhancer components such as Betaine (20\%), 7 Deaza GTP $(50 \mu \mathrm{M})$, DMSO (5\%) were used in the PCR reaction mixture [14]. The full-length coding sequence (CDS) of the human ADAMTS2 gene variant 2 mRNA sequence was used for designing primers. cDNA of MG-63 (Osteosarcoma cell line) was used as a template and amplified using primers 5'GAATGGATCCGCCGGCGGGAGC'3 and 5'TCAGGCGATCCACCTACCTTGGCC'3 (GenBank accession no. NM_021599). Taq DNA Polymerase (Thermo Scientific) was used for the PCR reaction, and the $1700 \mathrm{bp}$ PCR product was cloned into pGEM-T Easy vector (Promega) with TA cloning system and then subcloned into pcDNA 3.1/V5-His A vector at the EcoRI restriction sites. pcDNA 3.1/V5 was dephosphorylated before ligation reaction. A clone was sequenced (REFGEN, Ankara) using ADAMTS2 sequencing primer and cloning primers to confirm the sequence integrity. ADAMTS2 Sequencing primers were 5'-TGG CGC TCA GCA ACT GCG AT-3' and 5'-AAG CCG TCC TCA TGG TTC AG-'3.

\subsection{Cell culture and MTT assay}

Saos-2 cells were cultured in Dulbecco's Modified Eagle Medium (DMEM) supplemented with $10 \%$ Fetal Calf Serum (FCS) under humidified air at $37^{\circ} \mathrm{C}$ containing $5 \% \mathrm{CO}_{2}$. Cell viability was controlled by trypan blue exclusion. $150 \mu \mathrm{M}$ final concentration of $\mathrm{CoCl}_{2}$ (Cobalt Chloride)

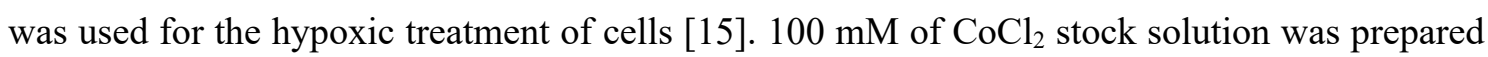
in $\mathrm{dH}_{2} \mathrm{O}$ and further diluted in cell medium to obtain the final concentration.

Cell cytotoxicity analysis was determined by MTT (3-(4,5-Dimethylthiazol-2-yl)-2,5Diphenyltetrazolium Bromide) assays [16]. For MTT test, 50000 cells/well were seeded in a 96well microplate at $37^{\circ} \mathrm{C}$. One day after seeding the cells, four different concentrations of samples in a range between $50 \mu \mathrm{M}$ and $200 \mu \mathrm{M} \mathrm{CoCl}_{2}$ were treated in the cells for 24 hours. Untreated cells were also included as a comparison. The absorbance was measured with a spectrophotometer (Thermo Scientific) at $550 \mathrm{~nm}$. Independent two experiments were done at least triplicate.

\subsection{Transient transfection of the expression vector}

pcDNA3.1 expression vector which contained ADAMTS2 gene and SEAP (Secreted Alkaline Phosphatase Plasmid) control (Takara, Clontech) vector were transiently transfected into Saos-2 cells by calcium-phosphate precipitation method [15]. SEAP plasmid was used for internal control of transfection. The secreted SEAP activities in cell medium were measured using Ready 
to Glow Secreted luciferase kits (Takara, Clontech) in Luminometer (Thermo, USA). Each transfection was repeated at least three times. For transient transfection assay, 500.000 cells/well were seeded in a 6 -well plate at $37^{\circ} \mathrm{C}$. The cell medium was changed 6 hours after transfection and cells were treated with $150 \mu \mathrm{M} \mathrm{CoCl}_{2}$ for 24 hours. Non-treated cells were used as control cells.

\subsection{RNA isolation and quantitative real time-PCR (qRT-PCR)}

For RNA analyses, 2000.000 cells/well were seeded in a $25 \mathrm{~cm}^{2}$ cell culture flask at $37^{\circ} \mathrm{C}$. Cells were treated with $150 \mu \mathrm{M} \mathrm{CoCl}_{2}$ for 24,48 , and 72 hours. The GeneJET ${ }^{\mathrm{TM}}$ RNA Purification Kit was used to extract total RNA according to the manufacturer's recommendation (Thermo Scientific). RNA concentrations were determined by spectrophotometer. Revert Aid Reverse Transcriptase (Thermo Scientific) was used to generate for cDNA synthesis. SYBR Green Master Mix (Roche) was used for Real-Time PCR (Roche LightCycler 480 Instrument) analyses in 96 well-plates in a final volume of $10 \mu \mathrm{L}$ by adding $1 \mu \mathrm{L}$ cDNA (synthesized with 1000ng of RNA), $0.5 \mu \mathrm{L}$ forward primer $(100 \mathrm{ng} / \mu \mathrm{L}), 0.5 \mu \mathrm{L}$ reverse primer $(100 \mathrm{ng} / \mu \mathrm{L}), 3 \mu \mathrm{L} \mathrm{dH}_{2} \mathrm{O}$ and $5 \mu \mathrm{L}$ SYBR Green PCR Master Mix. ADAMTS2, HIF1 $\alpha$, and human $\beta 2$ microglobulin ( $\beta 2 \mathrm{M})$ gene-specific primers were used. The expression primer sequences for ADAMTS2 were as follows; 5'-CTG TGG CGA CGA GGT GCG-'3 and 5'-GGT GCA CAC ATA GTC CCG TCC-'3. $\beta 2 \mathrm{M}$ primers were used as an internal control. $\beta 2 \mathrm{M}$ primer sequences were 5'-TTT CTG GCC TGG AGG CTA TC-‘3 and 5'-CAT GTC TCC ATC CCA CTT AAC T-‘3 HIF-1 $\alpha$ expression primer sequences were 5'-CCA CCT ATG ACC TGC TTG GT-'3 and 5'-TGT CCT GTG GTG ACT TGT CC-'3. Product specificity was analyzed with a melting curve analysis. The results were analyzed with the LIVAK method [17].

\subsection{Colony formation assay}

For colony formation assay 200 cells/well were seeded in a 6-well plate and transfected with pcDNA3.1 vector containing ADAMTS2. The cell medium was changed 6 hours after transfections and $150 \mu \mathrm{M} \mathrm{CoCl}_{2}$ were treated to the cells. The medium of the cells was changed every 2 days for normoxic and hypoxic groups and colonies were visualized after 10 days. Cells were plated in a six-well plate at 200 cells per well. Hypoxic stimulation cells were treated with $150 \mu \mathrm{M} \mathrm{CoCl}_{2}$ and the non-transfected group was used as a control group. The medium of the cells was changed every 2 days and colonies were visualized after 10 days. For this purpose, the plates were fixed with cold methanol for 10 minutes and stained with $0.1 \%$ crystal violet for 15 minutes [18]. Plates were photographed and the colony numbers were counted with the Image $\mathrm{J}$ program. 


\subsection{Statistical analysis}

One-way analysis of variance (ANOVA) was used for statistical analysis in Minitab, $p$ values of 0.05 or less were accepted for statistical significance of a probability $(\mathrm{P})$.

\section{Results}

\subsection{MTT test for cytotoxic effect of $\mathrm{CoCl}_{2}$}

MTT test was done to determine the effect of different $\mathrm{CoCl}_{2}$ concentrations on Saos-2 cells. Saos-2 cells were plated in 96 well-plates counting 50,000 cells into each well. A day after, different concentrations ( $50 \mu \mathrm{M}, 100 \mu \mathrm{M}, 150 \mu \mathrm{M}, 200 \mu \mathrm{M}$ ) of $\mathrm{CoCl}_{2}$ solution were added to the cells in 96-well plates. The $550 \mathrm{~nm}$ absorbance values of the treated cells were compared with the control group cells. No cytotoxic effect of $\mathrm{CoCl}_{2}$ on Saos-2 cells was observed at applied doses (Fig. 1A).

A

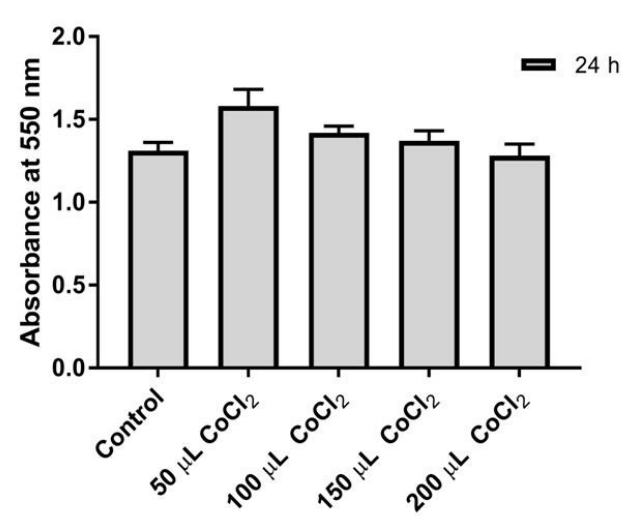

B

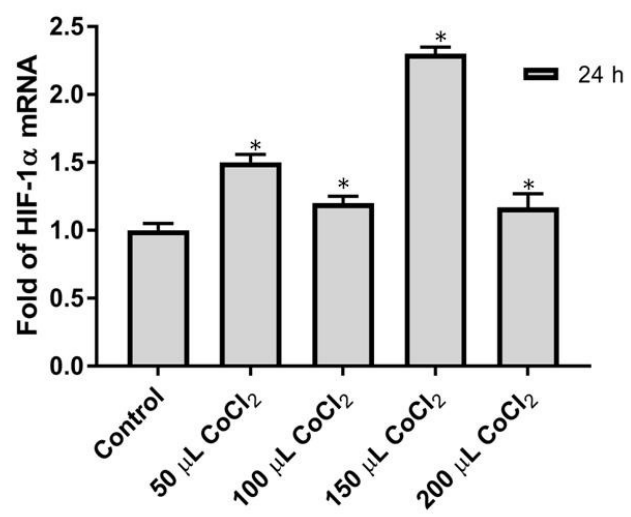

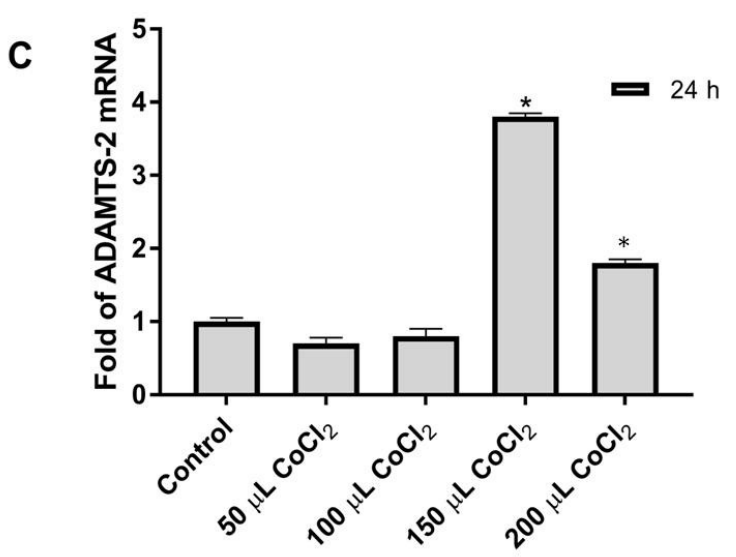

Figure 1: Effects of $\mathrm{CoCl}_{2}$ at different concentrations on cytotoxic and gene expression in Saos-2 cells were shown; (A) MTT Analysis was performed as described above in Saos-2 cells, (B) The relative mRNA expression level of HIF-1 $\alpha$ was determined in Saos- 2 cells, (C) The relative mRNA level of ADAMTS2 was determined in Saos-2 cells. ${ }^{*} \mathrm{p}<0.05$ 


\subsection{Verification of hypoxia with q-PCR and detection of ADAMTS2 mRNA level}

Saos- 2 cells were plated into $25 \mathrm{~cm}^{2}$ flasks in a $5 \mathrm{ml}$ medium containing 2,000,000 cells. Different concentrations of $\mathrm{CoCl}_{2}$ were added to the cell media of the hypoxia plates the following day. The cells were pelleted at $24 \mathrm{~h}$ and total RNA was isolated from pellets. cDNA synthesis was performed as $1 \mu \mathrm{g}$ of total RNA. ADAMTS2, $\beta 2 \mathrm{M}$, and HIF-1 $\alpha$ mRNA levels were determined in Saos- 2 cells at different concentrations of $\mathrm{CoCl}_{2}$. The highest HIF-1 $\alpha$ response was detected in $150 \mu \mathrm{M} \mathrm{CoCl}_{2}$ treated cells (Fig. 1B). Also, the highest ADAMTS2 expression was detected at the same concentration of $\mathrm{CoCl}_{2}$ (Fig. 1C). Consequently, considering both MTT and Real-Time PCR results, it was determined that $150 \mu \mathrm{M} \mathrm{CoCl}_{2}$ was suitable for hypoxia stimulation.

\subsection{The control of transient transfection and ectopic ADAMTS2 expression}

Cells were plated in $25 \mathrm{~cm}^{2}$ flasks and the next day, cells were transfected with pCDNA3.1 $(8 \mu \mathrm{g})$ and SEAP $(2 \mu \mathrm{g})$ vectors using calcium phosphate precipitation method. The SEAP vector was used for transfection control. The cell medium was collected after transfection at $24 \mathrm{~h}, 48 \mathrm{~h}$ and $72 \mathrm{~h}$. Secreted alkaline phosphatase activities were measured. For RNA analysis, cells were centrifuged and RNA isolation was performed from pellets. cDNA synthesis was performed from both control and experimental groups with 1000ng RNA. SEAP activity has reached a detectable level compared to the non-transfected control group. These results showed that the transfection was working. ADAMTS2 mRNA expression was determined by RealTime PCR. $\beta 2 \mathrm{M}$ mRNA expression was used as an internal control. ADAMTS2 expression was increased 50-fold in the experimental group transfected with pCDNA3.1 vector containing ADAMTS2. This result showed us that ADAMTS2 expression occurred ectopically in Saos-2 cells.

\subsection{Colony formation in ADAMTS2 transfected Saos-2 cells}

Saos-2 cells were counted with the trypan blue method and plated in 6 well plates. After 24 hours, cells were transfected with the pcDNA3.1 vector containing the ADAMTS2 gene. We compared two transfected groups of cells named transfected in normoxia and transfected in hypoxia. $\mathrm{CoCl}_{2}$ was applied to a transfected group and marked as a hypoxic group. The other transfected group was left under normal conditions and marked as the normoxic group. The medium was replaced with fresh medium every two days, and at the end of 10 days cells medium was removed and the cells were treated with cold methanol for 10 minutes for fixation. After fixation cells were treated for 15 minutes with crystal violet dye. Stained cell colonies in well plates were photographed and the colonies were counted with image J. 
A

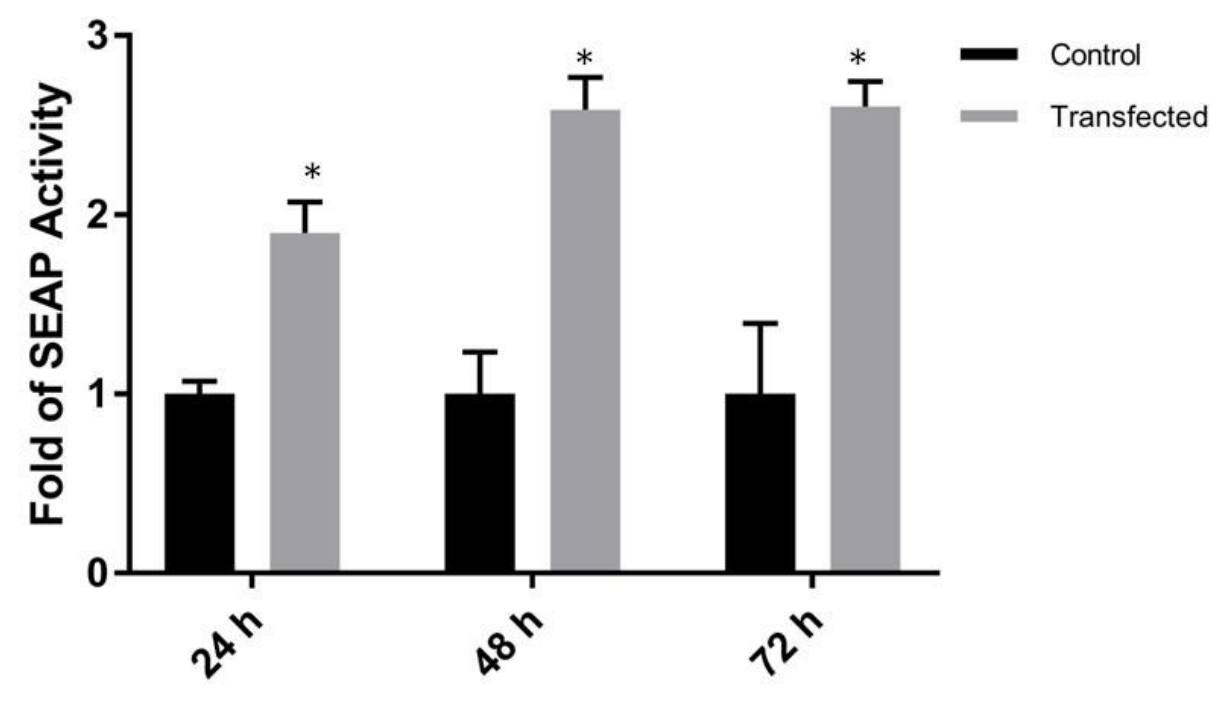

B

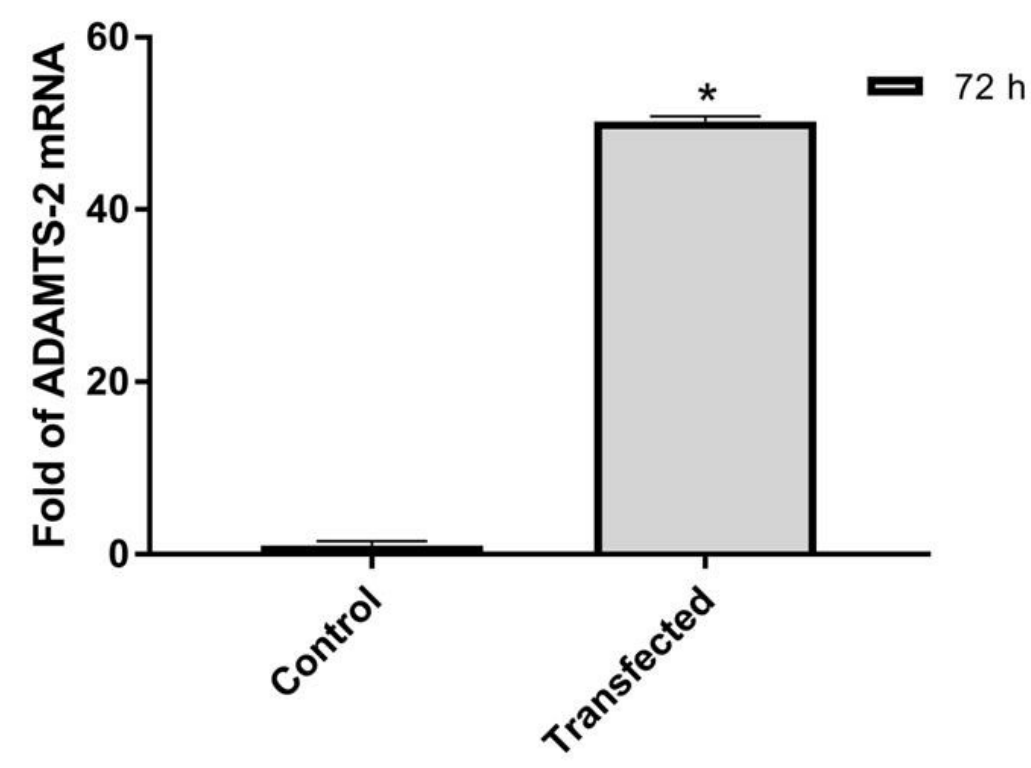

Figure 2: Ectopic ADAMTS2 expression was controlled at the mRNA level (A) Transfection efficiency was controlled using SEAP2 Activity in Saos-2 cells (B) Confirmation of ADAMTS2 Ectopic Expression in Saos-2 cells by Real-Time PCR *p $<0.05$

As seen in Fig. 3, when the normoxic transfected group and the hypoxic transfected group were compared, the reducing effect of ADAMTS2 ectopic expression on colony formation in cells under hypoxic conditions was determined. 
A

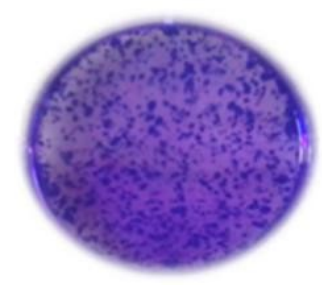

Control

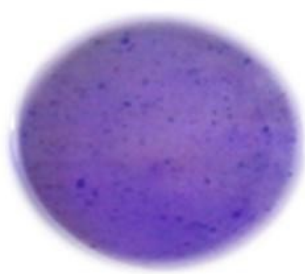

Normoxia Transfected + ADAMTS-2

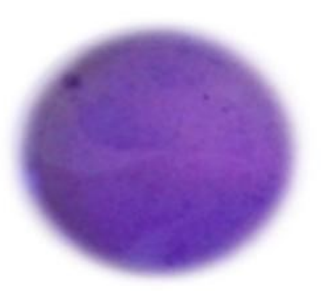

Hypoxia Transfected + ADAMTS-2

B

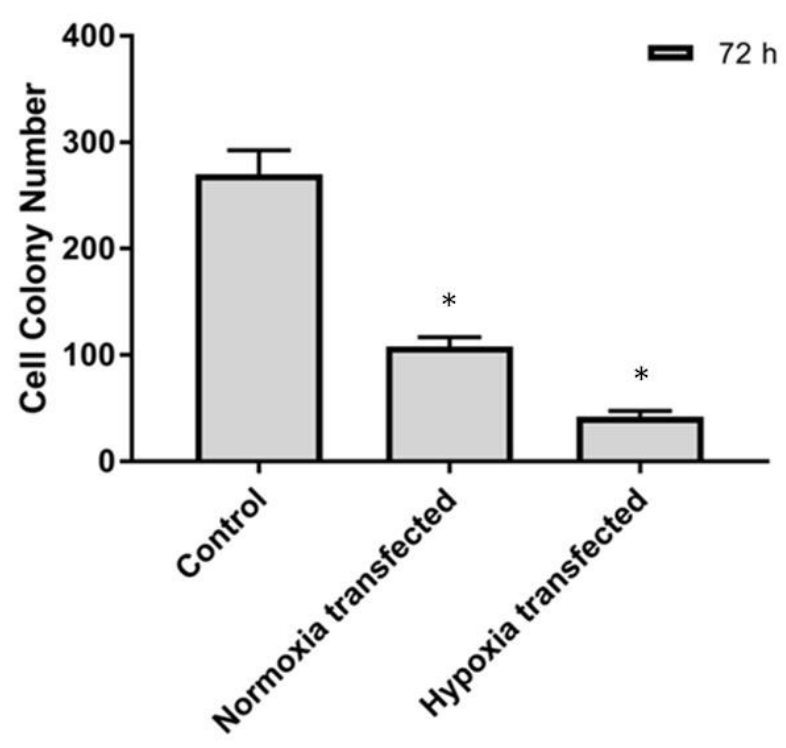

Figure 3: Colony formation effect of ADAMTS2 in Saos-2 cells; Cells were transfected with a pcDNA 3.1 vector containing ADAMTS2. For hypoxic stimulation cells were treated with $150 \mu \mathrm{m} \mathrm{CoCl}$. (A) Stained cell colonies photographed in 6 well plates. (B) The colonies counted with Image J and statistically analyzed. ${ }^{*} \mathrm{p}<0.05$

\section{Discussion}

The primary task of ADAMTS2, defined as amino procollagen peptidase, is to break down the amino propeptides of type I, II, III, and V procollagen. [1, 2, 9]. ADAMTS2 protein is synthesized in an inactive zymogen form and the N-terminal propeptide portion is cut with furin enzyme. This post-translational modification is necessary for the activity of the protein [19]. ADAMTS2 deficiency causes dermatosparaxis (Ehlers - Danlos syndrome type VIIC), a connective tissue disease with recessive inheritance in humans $[20,21]$. This hereditary connective tissue disorder occurs as a result of the accumulation of improperly processed amino procollagen, and the main feature of the disease is skin fragility [10, 22]. ADAMTS2 has been found to exhibit antiangiogenic properties via nucleolin in vivo and in vitro, which is associated with the cell membrane [10]. In a study, the anti-angiogenic feature of ADAMTS2 was determined. It was observed that tumor formation rapidly decreased when ADAMTS2 was 
overproduced. In vitro studies have shown that recombinant ADAMTS2 rapidly induces apoptosis of endothelial cells [10].

ADAMTS2 has been reported as a tumor suppressor protein due to its anti-angiogenic properties. It has been argued that its function may be impaired by chromosomal rearrangement involving ADAMTS2. It has been thought that rearrangement of the ADAMTS2 gene may be responsible for the production of an active protein [19]. In another study, IL-6 was found to transcriptionally regulate the ADAMTS2 gene in Saos-2 cells and increase the mRNA and protein level of ADAMTS2 [23]. In another regulation study, IL-1 $\alpha$, a proinflammatory cytokine, has been shown to increase gene expression in ADAMTS2 and ADAMTS-3 in Saos-2 and MG-63 cells [24].

Oxygen $\left(\mathrm{O}_{2}\right)$ homeostasis is very important for vertebrate life. Expression of many genes related to angiogenesis, glucose metabolism, cell proliferation, and regulation of physiological response is increased by HIF-1 at low $\mathrm{O}_{2}$ levels [25]. Hypoxic conditions occur in the microenvironment of the tumor [26]. Hypoxia is regulated by the HIF-1 transcription factor in mammalian cells [27]. HIF-mediated intracellular pathways are active in the development, physiology, and pathophysiological processes. Gene products targeted by HIF-1 are divided into two distinct categories: proteins that increase $\mathrm{O}_{2}$ efficiency and decrease $\mathrm{O}_{2}$ consumption. In particular, the vast majority of human tumors have overexpression of these gene products [28]. Tumor cells stimulate molecular programs such as cell proliferation, cell survival, and angiogenesis in response to hypoxia. Overexpression of HIF-1 has been demonstrated by immunohistochemical analysis in prostate, lung, breast, colon, ovarian, skin, and stomach in many human malignant cancers [29]. For the first time in our study, ectopic expression of the ADAMTS2 gene in Saos-2 cells was investigated under both normal and hypoxic conditions. A chemical hypoxia mimetic agent $\mathrm{CoCl}_{2}$ was used for hypoxic stimulation. $\mathrm{CoCl}_{2}$ was applied to the cells at different concentrations and it was determined at what dose the optimal response occurred. In our previous study, the ADAMTS2 mRNA level was tested in different cell lines in hypoxic conditions. It has been determined that the ADAMTS2 mRNA level is increased in hypoxia in DU-145, PC-3, HT-29, MCF-7, and Saos-2 cells. The highest hypoxic response was observed in Saos-2 and MCF-7 cells [30]. ADAMTS2 is expressed in a variety of adult tissues, including heart tissue, and takes part in a large number of physiological processes. Increased expression of ADAMTS2 was observed in coronary lesion samples from patients with acute myocardial infarction. During acute myocardial infarction, cells remain oxygen-free and a hypoxic microenvironment is formed. ADAMTS2 has been shown to play a potential role in the pathogenesis of acute myocardial infarction and cardiovascular disease [21]. 
The hypoxic microenvironment is very important for the progression and spread of cancer in pathophysiological processes, especially in the process of cancer. In our study, the effect of overexpression of the ADAMTS2 gene, which is involved in collagen metabolism and has antiangiogenic activity, was investigated in the formation of cells in both normal and hypoxic conditions. The ADAMTS2 gene was cloned into the expression vector and was produced ectopically in Saos-2 cells. The effect of ADAMTS2, which is overexpressed in Saos-2 cells for the first time, has been investigated in hypoxic conditions. The inhibitory effect of ADAMTS2 overexpression on cells was found.

To fully clarify the role of ADAMTS2 protein in the cancer process, hypoxic conditions also need to be taken into consideration.

\section{Conclusion}

As a result, ectopically overexpressed ADAMTS2 decreased the colony formation of Saos2 cells in hypoxic conditions. We suggest that the hypoxic conditions should be examined for a more detailed understanding of the regulation of the ADAMTS2 gene.

\section{Acknowledgment}

Balikesir University Scientific Research Projects Units (BAP) projects 2015/42, was the primary sponsor of this study. The authors would like to thank Dr. Kenneth Brown, University of Cardiff, UK for the human osteogenic sarcoma cell line (Saos-2).

\section{References}

[1] K1lıç, M.Ö., Aynekin, B., Kılıç, Y., Demircan K., Bozer M., ADAMTS Proteases in Cancer, New Journal of Medicine, 32, 123-127, 2015.

[2] Brodsky, B., Persikov, A. V., Molecular structure of the collagen triple helix, Advances in Protein Chemistry, 70, 301-339, 2005.

[3] Khun, K., Mayne, R., Burgeson, R., Structure and Function of Collagen Types, Academic, Orlando, Florida, 1987.

[4] Robert, P.M., The Extracellular Matrix: An Overview, Springer, Berlin, 2011.

[5] Lodish, H., Berk, A., Kaiser, C.A., Krieger, M., Scott, M.P., Bretscher, A., Ploegh, H., Matsudaira, P., Moleküler hücre biyolojisi, Ahr, K., Tontonoz, M., Pantages, E.F., Rice, E., Palme Yayınc1lı, Ankara, 2007.

[6] Persikov, A.V., Brodsky, B., Unstable molecules form stable tissues, Proceedings of the National Academy of Sciences, 99(3), 1101-1103, 2002.

[7] Rocks, N., Paulissen, G., El Hour, M., Quesada, F., Crahay, C., Gueders, M., Foidart, ADAM-8, a metalloproteinase, drives acute allergen induced airway inflammation, 41, 2, European Journal of Immunology, 380-391, 2011. 
[8] Chou, C.W., Chen, C.C., HDAC inhibition upregulates the expression of angiostatic ADAMTS1, FEBS Letters, 582, 4059-4065, 2008.

[9] Colige, A., Vandenberghe, I., Thiry, M., Lambert, C. A., Van Beeumen, J., Li, S. W., Cloning and characterization of ADAMTS-14, a novel ADAMTS displaying high homology with ADAMTS-2 and ADAMTS-3, Journal of Biological Chemistry, 277(8), 5756-66, 2002.

[10] Dubail, J., Kesteloot, F., Deroanne, C., Motte, P., Lambert, V., Rakic, J.M., Lapiere, C., Nusgens, B., Colige, A., Adamts-2 Functions as Anti-Angiogenic and Anti-Tumoral Molecule Independently of Its Catalytic Activity, Cellular and Molecular Life Sciences, 67(24), 4213-4232, 2010.

[11] Malagelada, C., Xifro, X., Minano, A., Sabria, J., Alvarez, J.A., Contribution of caspase-mediated apoptosis to the cell death caused by oxygen-glucose deprivation in cortical cell cultures, Neurobiology of Disease, 20(1), 27-37, 2005.

[12] Ouyang, Y.B., Xu, L., Giffard, R.G., Geldanamycin treatment reduces delayed CA I damage in mouse hippocampal organotypic cultures subjected to oxygen glucose deprivation, Neuroscience letters, 380(3), 229-233, 2005.

[13] Semenza, G.L., Surviving ischemia: adaptive responses mediated by hypoxiainducible factor 1, Journal of Clinical Investigation, 106(7), 809-812, 2000.

[14] Alper, M., Tokay, E., Kockar. F., Amplification of GC Rich ADAMTS-2 and URG4/URGCP Promoter Regions with Optimised Combination of PCR Enhancers, Turkish Journal of Biology, 40(1), 196-205, 2015.

[15] Aydogan Turkoglu, S., Kockar, F., SPI and USF differentially regulate ADAMTS1 gene expression under normoxic and hypoxic conditions in hepatoma cells, Gene, 575(1), 48-57, 2016.

[16] Aydogan Turkoglu, S., Okuyan, D., Kockar, F., TGF- $\beta$ downregulates CAIII expression via MAPK and PI3K signaling pathways in colon carcinoma and osteosarcoma cells, Archives of Biological Sciences, 7(3), 393-401, 2019.

[17] Livak, K.J., Schmittgen, T.D., Analysis of relative gene expression data using realtime quantitative PCR and the 2 (-Delta Delta C(T)) Method, Methods 25 (4), 402-408, 2001.

[18] Daiy, H., Huangy, Y., Li, Y., Meng, G., Wang, Y., Guo, Q., TSSC3 overexpression associates with growth inhibition, apoptosis induction and enhances chemotherapeutic effects in human osteosarcoma, Carcinogenesis 33(1), 2012.

[19] Tota, G., Coccaro, N., Zagaria, A., Anelli, L., Casieri, P., Cellamare, A., Minervini, A., Minervini, C.F., Brunetti, C., Impera, L., Carluccio, P., Cumbo, C., Specchia, G., Albano, F., Adamts2 Gene Dysregulation in T/Myeloid Mixed Phenotype Acute Leukemia, BMC Cancer, 14(1), 963, 2014.

[20] Le Goff, C., Somerville, R.P., Kesteloot, F., Powell, K., Birk, D. E., Colige, A. C., Apte, S. S., Regulation of Procollagen Amino-Propeptide Processing During Mouse Embryogenesis by Specialization of Homologous Adamts Proteases: Insights on Collagen Biosynthesis and Dermatosparaxis, Development and Disease, 133(8), 1587-96, 2006.

[21] Wang, X., Chen, W., Zhang, J., Khan, A., Li, L., Huang, F., Qiu, Z., Wang, L., Chen, X., Critical Role of Adamts2 (a Disintegrin and Metalloproteinase with Thrombospondin Motifs 2) in Cardiac Hypertrophy Induced by Pressure Overload, Hypertension, 69(6), 1060-1069, 2017.

[22] Colige, A., Ruggiero, F., Vandenberghe, I., Dubail, J., Kesteloot, F., Van Beeumen, J., Beschin, A., Brys, L., Lapiere, C.M., Nusgens, B., Domains and Maturation Processes That 
Regulate the Activity of Adamts-2, a Metalloproteinase Cleaving the Aminopropeptide of Fibrillar Procollagens Types I-Iii and V, Journal of Biological Chemistry, 280(41), 34397-34408, 2005.

[23] Alper, M., Kockar, F., Il-6 Upregulates a Disintegrin and Metalloproteinase with Thrombospondin Motifs 2 (Adamts-2) in Human Osteosarcoma Cells Mediated by Jnk Pathway, Molecular and Cellular Biochemistry, 393(1-2), 165-75, 2014.

[24] Alper, M., Aydemir, A.T., Kockar, F., Induction of human ADAMTS-2 gene expression by IL-1 alpha is mediated by a multiple crosstalk of MEK/JNK and PI3K pathways in osteoblast like cells, Gene, 573(2), 321-327, 2015.

[25] Semenza, G.L., Oxygen Sensing, Hypoxia-Inducible Factors, and Disease Pathophysiology, Annual Review of Pathology: Mechanisms of Disease, 9, 47-71, 2014. 2016.

[26] Rankin, E. B. Giaccia, A.J., Hypoxic Control of Metastasis, Science, 352, 175-180,

[27] Semenza, G.L., Nejfelt, M. K., Chi, S.M., Antonarakis, S. E., Hypoxia Inducible Nuclear Factors Bind to an Enhancer Element Located 3' to the Human Erythropoietin Gene, Proceeding of the National Academy of Sciences USA, 88(13), 5680- 5684, 1991.

[28] Balamurugan, K., Hif-1 at the Crossroads of Hypoxia, Inflammation, and Cancer, International Journal of Cancer, 138(5), 1058-1066, 2016.

[29] Brusselmans, K., Bono, F., Maxwell, P., Dor, Y., Dewerchin, M., Collen, D., Herbert, J. M., Carmeliet, P., Hypoxia-inducible factor $2-\alpha(H I F-2 \alpha)$ is involved in the apoptotic response to hypoglycemia but not to hypoxia, Journal of Biological Chemistry, 276, 39192-39196, 2001.

[30] Aydogan Turkoglu, S., Gultekin, A. S., Kockar, F., Variation of ADAMTS2 Gene Expression in Hypoxic Conditions in Cancer, Afyon Kocatepe University Journal of Sciences and Engineering, 19(1), 22-33, 2019. 